\title{
MODERNIDADE E EDUCAÇÃO EM ÉMILE DURKHEIM
}

Ely Guimarães dos Santos Evangelista

RESUMO: Este texto procura associar a questão da modernidade às categorias sociológicas de Durkheim. Neste contexto, interessa em primeiro lugar sua noção de pedagogia e de como se associam, na sua teoria, educação, moral e sociologia.

UNITERMOS: pedagogia, sociologia, educação.

\section{INTRODUÇÃO}

A sociologia de Durkheim, que o situa entre os clássicos da ciência social, consiste numa resposta aos problemas e dilemas postos pelo vira-ser da modernidade, que se sobrepõe, conflitivamente, aos resquícios da velha ordem ainda presentes na sociedade francesa ao tempo da consolidação da Terceira República. Sua preocupação com a ordem, numa sociedade dividida e moralmente abatida, se concretiza num trabalho persistente e rigoroso no sentido de delimitar o objeto da sociologia em sua especificidade e de estabelecer as regras do método de investigação sociológica. Ao mesmo tempo, é levado pela amplitude dos problemas, cuja explicação se apresenta como um desafio, a expandir o alcance da nova ciência, que se apresenta como ciência da moral, ciência 
da educação e ciência das instituições, mas também como ciência dos ideais. O resultado consiste numa teoria da investigação sociológica e numa teoria da sociedade como um todo, em suas dimensões econômica, jurídico-política, moral, religiosa, cultural, científica, filosófica e educacional, abrangendo a estática e a dinâmica social, a constituição, o desenvolvimento e a manutenção da sociedade representada nas consciências individuais, como fato e como ideal coletivo.

Sensível à emergência de novos valores e novas sociabilidades precondição para a reconstrução da nação, que deve se adequar ao modo de ser moderno, que a projeta para o futuro -, Durkheim articula uma teoria da educação que se fundamenta numa teoria da sociedade, cujo aspecto inovador, a despeito de seu cunho normativo, freqüentemente ressaltado pela crítica de seu pensamento, assim como do aspecto conservador atribuído a sua perspectiva positivista, consiste no recurso à história e no rigor metodológico para a explicação da educação, sempre referida ao homem concreto de uma sociedade, situado e datado, porém resultado de realizações pretéritas, cuja gênese clarifica o presente, condição para a antecipação do futuro inscrito na representação que a sociedade faz de si mesma.

As questões a partir das quais Durkheim problematiza a educação enquanto fato social explicável pela sociedade, muitas das quais ainda nos preocupam hoje, permitem vê-lo também como um clássico do pensamento educacional e justificam o objetivo de, neste ensaio, sistematizar uma leitura de suas formulações teóricas referentes à relação sociedade-indivíduo-educação. 


\section{SOCIEDADE E INDIVÍDUO}

Qualquer sociedade é uma sociedade moral. (...) Porque o indivíduo não se basta, é da sociedade que recebe tudo que lhe é necessário, como é para cla que ele trabalha".

(DTS, v. 1, p. 261) ${ }^{1}$.

Por que os indivíduos se associam? Por que se constituem em sociedades cada vez mais vastas e complexas? Como as sociedades se constituem, se transformam e se mantêm? Como se situa, neste processo, o indivíduo? São estas as questões-guia que parecem relevar do íntimo da sociologia de Durkheim. Pensar nelas possibilita compreender o que é a sociedade, bem como a relação sociedade-indivíduo em seu sistema, e o significado da educação no seu pensamento.

Da definição dos fatos sociais como coisas decorre a característica essencial dos mesmos de exercerem, por sua exterioridade, uma coerção sobre as consciências individuais. Desta perspectiva, Durkheim toma distância em relação à sociologia que o precedera. Esta, fundando a explicação da sociedade na consciência individual, terminava por recorrer à psicologia. Já no pensamento durkheimiano, não é do indivíduo que "pode provir a pressão exterior que [ele] sofre" (RMS, p. 89), mas da sociedade, totalidade viva que ultrapassa os indivíduos no tempo e no espaço, supera-os, tem autoridade sobre eles, que diante dela se inclinam.

São, contudo, os temas comteanos que inspiram Durkheim a postular como "aparente" a "antinomia" indivíduo-sociedade e a procurar a explicação dos conflitos de que sua sociedade é palco, "na transformaşão da solidariedade social devido ao desenvolvimento sempre mais considerável da divisão do

\footnotetext{
${ }^{1}$ As obras de Durkheim serão citadas ao longo do ensaio em forma de siglas. Nas referências bibliográficas, ao final do texto, apresentam-se os títulos e referências das obras a que se referem as siglas utilizadas.
} 
trabalho" (DTS, v. 1, p. 49). Adverte, porém, que se esta divisão e seus efeitos são mais vivamente percebidos na atividade econômica, não se restringem a esta área da sociedade. A política, a administração, a educação, a área jurídica, a ciência, a arte são áreas em que esse fenômeno cada vez mais se faz sentir.

Percebida de "maneira confusa" pela "consciência moral das nações", esta questão tem "dividido os espiritos" no que se refere à apreciação do seu valor, resultando duas orientações diversas quanto à formação do homem: formação intensiva, voltada à função de integrar os esforços dos indivíduos no organismo social, e formação geral, extensiva, que destina o homem a bastar-se a si próprio (DTS, v. 1, p. 54). Assim, o estudo científico da divisão do trabalho social tem um sentido prático, uma vez que a segunda orientação é inaceitável, pois o indivíduo, longe de ser um eu, é, na verdade, um nós (CSA, p. 114).

Este é um dilema que perpassa toda a obra de Durkheim, em sua reflexão sobre a relação indivíduo-sociedade : uma concepção dual da natureza do homem, ser único permanentemente dividido em pólos antagônicos, egoísmo e altruísmo, respectivamente referidos ao ser individual, cujos desejos e paixões são infinitos, e ao ser moral, numa sociedade anômica que estimula o primeiro destes pólos, com vistas ao progresso, em face do qual Durkheim parece hesitar entre recusa e aceitação. 'Não bá ideal moral que não alie, em proporções que variam consoante as sociedades, o egoísmo, o altruísmo e uma certa anomia. (...) a vida social pressupõe simultaneamente que o individuo tenha uma certa personalidade de que estará pronto a abdicar se a comunidade assim o exigir, e que seja de certa forma receptivo às idéias de progresso. É por isso que não existe nenbum povo em que não coexistam estas três correntes de opinião que solicitam o bomem em três direções divergentes e até mesmo contraditórias" (OS, p. 319). O equilíbrio, pois, destas três correntes de opinião é condição para a saúde da vida social, cuja tendência crescente em direção à socialização inclui o individualismo moral, não utilitário. 
Individualismo e socialismo se revelam assim como antinomia aparente, pois, no curso de seu desenvolvimento, a sociedade tende à realização de ambos. Contrário à agressividade destrutiva que percebe na noção de luta de classes invocada como meio de construção de uma sociedade justa, Durkheim assevera que somente o conhecimento das leis sociais permite intervir nas causas que produzem os fenômenos sociais, a fim de acelerar o desenvolvimento da sociedade, que em sua essência se caracteriza pela democracia ${ }^{2}$ e pela justiça social, como demonstra a crescente socialização das atividades sociais. "Não se compreende em virtude de que privilégio as funções econômicas seriam as únicas em estado de resistir a este movimento" (CS A, p. 208). O socialismo não é contrário à natureza das sociedades capitalistas, mas "conforme à sua evolução natural". Assim, prescinde de "as destruir para se instalar" (CSA, p. 263).

É necessário, pois, oferecer uma resposta científica à questão, o que significa perguntar pela função da divisão do trabalho social, pelas causas das quais ela depende e pelo modo como se classificam as formas anormais que ela apresenta. O pressuposto é de que o inegável avanço da divisão do trabalho resulta da ocorrência de regularidades resultantes das relações entre causa eficiente, que produz o fato social, e a função

\footnotetext{
${ }^{2}$ A democracia é definida por Durkheim como a "forma politica pela qual a sociedade chega à mais pura consciência de si mesma" não sendo esta uma invenção recente, mas o "caráter que vão assumindo cada vez mais as sociedades". Sua explicação está na centralização das forças coletivas no órgão governamental, no desenvolvimento e ampliação de sua comunicação com a "massa das consciências individuais" e no desenvolvimento da capacidade de reflexão que acompanha o processo de diferenciação dos indivíduos e de complexificação das sociedades. "(...) o regime de reflexão permite, ao cidadão, aceitar as leis do país com maior inteligência, portanto, com menor passividade. Por isso que bá comunicação constante entre os individuos e o Estado, o Estado já não é para eles, como força exterior, a imprimir-lhes impulso de todo mecânico", mas "a vida do Estado se liga à dos individuos, tal como a dos individuos se liga à do Estado" (LS, p. 81-3). Esta é, em síntese, uma explicação da coesão social pelo consenso e não pela coerção material, aspecto que, observadas as devidas diferenças (entre outras, a referente ao projeto de sociedade), aproxima Durkheim de Gramsci.
}

Temáticas, Campinas, 5(9/10):23-66, jan./dez. 1997 
deste na sociedade. Neste raciocínio, o meio social não só é visto como determinante, mas também como única possibilidade de se estabelecer relações de causalidade na explicação sociológica. $O$ que, em síntese, significa reivindicar, para a ciência social, o mesmo caminho até então seguido pelas ciências que, ao se tornarem autônomas, adotaram o princípio do determinismo universal.

A interpretação encontrada em $A$ Divisão do Trabalho Social, sobre a mobilização do instinto de conservação pela "intensificação da luta pela vida" num meio em que o volume e a concentração da população aumentam as necessidades a serem supridas e obrigam à diferenciação e à especialização individual e social, é retificada em As Regras do Método Sociológico, pela consideração do fato de que a luta pela vida não produz nem explica a divisão do trabalho, "se as diferenças individuais não estiverem já suficientemente aumentadas, devido à indeterminação da consciência comum e das influências bereditárias", cujos resultados se expressam nas divergências individuais no que se refere a uma "diversidade maior de gostos e de aptidões" ( $R M S$, p. 81), a partir dos quais os indivíduos, nas condições em que se encontram, se especializam.

Isto significa que a "divisão do trabalbo une ao mesmo tempo que opõe, faz convergir as atividades que diferencia, aproxima as que separa" (DTS, v. 2, p. 58), o que pressupõe a existência de uma sociedade já constituída e, nela, laços morais que ligam os indivíduos, condição sem a qual, mediante a diversidade de interesses, inevitavelmente haveria a dispersão dos indivíduos, em vez de sua especialização e conseqüente divisão das funções sociais, até então comuns, e em vez, ainda, da composição de um todo coerente e harmônico em que se ajustem as funções que se dissociam.

Este resultado tem como causas forças puramente mecânicas e se explica também pela forma de transição da estrutura social simples para a organizada. Esta última, em seu processo de constituição, "tenta utilizar a estrutura que existe e assimilá-la. A maneira pela qual as funções se dividem 
decalca-se então, tão fielmente quanto possivel, sobre a sociedade que se encontra já dividida" (DTS, v. 1, p. 212). Neste processo, que requer tempo, a oposição entre as duas estruturas evolui pela regressão da primeira e desenvolvimento da segunda, que vai se tornando preponderante. Os segmentos que constituíam a primeira transformam-se em órgãos articulados entre si e subordinados a um órgão central de função moderadora, o órgão governamental, que representa, a cada momento, o tipo psíquico da sociedade.

O desenvolvimento das sociedades se caracteriza, portanto, pela continuidade de transformação de uma estrutura social em outra. Estabilidade e mudança, instituído e instituinte se expressam na forma anatômica, isto é, o substrato material da vida coletiva - que compreende a base territorial e suas configurações geográficas, a massa de população que nele se combina de uma forma determinada, as vias de comunicação, o estado da técnica alcançado -, e na vida intelectual e moral que se desenvolve a partir deste substrato, isto é, a fisiologia do corpo social. Representações e ações, maneiras de ser, pensar, sentir e agir se constituem e se consolidam. A estrutura e a função, objetos, respectivamente, da morfologia social e da fisiologia social, na divisão da sociologia proposta por Durkheim, em que os fenômenos se distinguem por graus de consolidação (RMS, p. 11) e as estruturas são funções que se consolidaram (CSA, pp. 132-137 e p. 98).

Este é o sentido lógico e histórico da classificação dos tipos sociais $^{3}$. As sociedades, em que a coesão se dá pela divisão do trabalho, em que os indivíduos são unidos pelos laços da solidariedade orgânica, nascem das sociedades fundadas nas similitudes das consciências unidas

\footnotetext{
${ }^{3} \mathrm{Na}$ constituição dos tipos sociais se evidenciam aspectos pelos quais se creditam méritos à elaboração teórica de Durkheim em virtude do significado de seu empreendimento para uma teoria da investigação sociológica. Ver a respeito: FERNANDES, 1972 , p. $71-2$, p. 79 , p. 190-8.
} 
pela solidariedade mecânica. É a presença desta solidariedade e das normas que sancionam as rupturas de seus laços que possibilita a diferenciação das funções e a cooperação que esta supõe. Desenvolvida pelos "movimentos intestinos" (DTS, v. 2, p. 60) inerentes à complexificação da sociedade da divisão do trabalho, esta cooperação exige o desenvolvimento, por um lado, do Estado, cujas funções se ampliam e se diferenciam, e, por outro, do direito cooperativo, de sanções restitutivas.

A divisão do trabalho social tem, portanto um caráter moral, pois é moral a necessidade de ordem, de harmonia e solidariedade social, sendo assim contrária à anomia que caracteriza a realização das atividades econômicas, às formas patológicas da divisão do trabalho dela resultantes e às condições assim criadas, em que não se geram a solidariedade e o consenso espontâneo que em sua forma normal se produziriam, o que se manifesta no "estado de perturbação moral", nos "conflitos entre as classes", na elevação das taxas de crimes e de suicídio", na desarticulação ou integração insatisfatória entre os diversos órgãos do organismo social.

A constatação das formas anormais da divisão do trabalho e de seus resultados conduz à conclusão de que as sociedades superiores têm como tarefa "a realização de uma obra de justiça" que resulte numa igualdade nas "condições exteriores da concorrência" (DTS, v. 2, p. 205), aí incluindo,

+ Em seu estudo sobre o suicídio, que inaugura o uso da estatística na investigação sociológica, Durkheim considera a expressão da anomia e do individualismo utilitário nas correntes suicidogêneas, que contribuem para uma elevação das taxas de suicídio dos tipos egoísta, anômico e ego-anômico, nos centros comerciais e industriais em comparação com o meio agrícola, o que evidencia uma correlação positiva entre o suicídio patológico e a anomia da atividade econômica, característica da civilização industrial. Além destas, outras relações são estabelecidas, na explicação da incidência de suicídio em grupos diversos, como religião, família, exército. Em última instância, o problema se coloca em termos do dilema entre a vida individual e a vida coletiva tal como se desenvolve na sociedade moderna. 
além do respeito às aptidões naturais dos indivíduos, 'a extinção da herança e uma justa avaliação dos valores trocados, bem como a realização de uma disciplina moral, na qual as corporações profissionais, reorganizadas de modo a se adequarem às condições presentes, devem ser chamadas ao exercício de sua função moral que durante séculos exerceram ${ }^{5}$. Função semelhante é atribuída à escola, na qual a educação intelectual exigida pela sociedade moderna não se separa da educação moral, pela qual as novas gerações são construídas como seres morais.

O culto ao indivíduo, fundamento da moral nas sociedades da divisão do trabalho, é diverso do individualismo egoísta justificado pelo "progresso como dogma de fé". Aquele tem sua origem nos primeiros movimentos de diferenciação do indivíduo, e se assume na sociedade um caráter religioso é porque tem como alvo, não o indivíduo empírico, mas "o homem em geral, a bumanidade ideal, tal como a concebem os povos nos diferentes momentos de sua bistória".(OS, p. 336). Elemento constitutivo da divisão do trabalho social, este individualismo não afasta, ao contrário, une os indivíduos, "servidores" desta "obra comum", a sociedade, cuja realização lhes exige o elevarem-se acima de si mesmos, o sacrifício de seus interesses egoístas e a comunhão neste ideal.

Certo de que "o bem-estar médio aumentou a todos os niveis da bierarquia social ainda que nem sempre segundo proporções equiitativas", Durkheim conclui que "o mal-estar que sentimos (...) revela, não uma maior miséria econômica, mas uma alarmante miséria moral" (OS, p. 389), o que evidencia a necessidade do exercício de um poder moral que, sem comprimir, pela resignação, os desejos, não permita o "livre curso dos apetites". Este poder só pode vir da força moral da sociedade que, por meio de seus órgãos e da opinião pública, e em condições de justiça social, integre os indivíduos das

${ }^{5}$ É freqüente no pensamento durkheimiano a defesa da função social das corporações profissionais. O Prefácio à segunda edição de $A$ Divisão do Trabalbo Social é integralmente voltado para esta questão. $O$ mesmo tema é também abordado em $O$ Suicidio (p. 380-8). 
diferentes classes, em torno dos ideais coletivos. Em sua concepção, o sentimento de justiça social é inerente à "consciência moral das sociedades", de modo que "as diferentes funçoes estão como que bierarquizadas na opinião e um certo coeficiente de bem-estar é atribuido a cada um segundo o lugar que ocupa na bierarquia" (OS, p. 242).

O ideal moral de uma sociedade hierarquizada, cuja autoconsciência supõe a justiça social, assume expressão máxima no pensamento de Durkheim quando este se volta para o estudo da religião. A descoberta da importância da religião na vida social e da forma de abordá-la sociologicamente assinala, segundo ele próprio, uma reorientação no seu pensamento, após o curso sobre religião que ministrou em $1895^{6}{ }^{6}$

Nos estudos posteriores a 1895 , a crítica à perspectiva organicista presente em $A$ Divisão do Trabalho Social abre espaço à consideração dos ideais coletivos e sua eficácia própria. "Diminui-se a sociedade quando não se vê nela mais que um corpo organizado que tem por objetivo cumprir certas funç̃os vitais" (SF, p. 139); "a sociedade é, além disso, a morada de uma vida moral interior" (SF, p. 136). Trata-se da alma da sociedade, do conjunto dos ideais coletivos que "não são ideais abstratos, frias representacões intelectuais desprovidas de toda eficácia, mas são essencialmente motores, uma vez que atrás deles há forças reais $e$ atuantes: são essas as forgas coletivas, forgas naturais em consequiência, ainda que morais, comparáveis às forças que atuam no resto do universo" (SF, p. 139).

${ }^{6}$ Cf. ALPERT, 1986, p. 149, citação de Durkheim a este respeito. Estudiosos do pensamento de Durkheim têm ressaltado os aspectos sobre os quais incide esta reorientação: afastamento do determinismo da base morfológica e deslocamento da análise para os universos ideológicos (ORTIZ, 1989b, p. 8-11); ampliação e precisão da teoria da anomia, ampliação da concepção de causalidade e abandono do estudo sobre o socialismo (LACROIX, 1981, p. 120-144).

Temáticas, Campinas, 5(9/10):23-66, jan./dez. 1997 
Constituindo-se como um "conjunto de ideais", no qual o mais elevado é o ideal moral, e como "um sistema de forças", a sociedade é imperativa em relação ao indivíduo, coage-o e constrange. Pois ela só pode se manter e manter-se coerente "se existir entre os seus membros uma certa comunidade intelectual e moral" (CS $A$, p. 243). A sociedade, entretanto, também dá segurança ao indivíduo, por isso o atrai. $E$ se ele dela depende, também ela depende dele, assim como da função por ele exercida na hierarquia que compõe o todo do organismo social.

Obrigatoriedade e desejabilidade são, portanto, características fundamentais do fato moral. A incorporação do imperativo categórico kantiano não elimina, pois, o fato de que, "para que possamos nos desempenhar como sujeitos, é necessário que o ato desperte de alguma forma a nossa sensibilidade (...), que se apresente a nós de certo modo, como desejável’(SF, p. 58). A isto não se segue, porém, que a conduta moral não exija sempre do indivíduo o esforço e a contenção, ou até mesmo uma violência em sua individualidade empírica, o que se explica pela dualidade de sua natureza.

Poder-se-ia pensar, do exposto, na inexistência de espaço para a ação e para a originalidade individuais? Penso que não. $\mathrm{O}$ problema da liberdade e do sentido da ação, freqüentemente levantado pela crítica ao seu pensamento, o próprio Durkheim o considera em vários momentos de sua reflexão sobre a relação indivíduo-sociedade. Já em As Regras do Método Sociológico, ao concluir, para sua própria surpresa, sobre a normalidade do crime, chama a atenção para a necessidade de que a autoridade da "consciência moral não seja excessiva; doutra maneira, ninguém ousaria levantar a mão contra ela e ela se cristalizaria facilmente numa forma imutável. Para que evolua, é preciso que a originalidade individual possa vir a lume; ora, para que a originalidade do idealista, que sonba ultrapassar o seu século, se manifeste, é necessário que a do criminoso, que está abaixo do seu tempo, seja possivel" (RMS, p. 61).

Um exemplo caro a Durkheim, no sentido de afirmar a normalidade do crime e situá-lo como "parte integrante de toda sociedade sã" 
(RMS, p. 58), é o de Sócrates. Julgado e condenado como criminoso, por exercitar sua liberdade de pensamento na interrogação dos valores, individuais e sociais, Sócrates prestou, não só a sua cidade, como à humanidade em geral, a grande contribuição de situar a moral em sua dimensão filosófica, isto é, da reflexão, cuja importância fundamental, enquanto atitude e enquanto prática, Durkheim não se cansa de ressaltar.

Em seus estudos sobre a religião e a educação, a perspectiva da transformação da sociedade, vista na eficácia dos universos ideológicos, é exemplificada por Durkheim na ação dos indivíduos e grupos em momentos históricos, como as Cruzadas, a Reforma, a Revolução Francesa, nos quais, pela intensificação das interações sociais, se produzem "efervescências revolucionárias" criadoras de novos ideais que ativam as paixões e as ações dos homens na luta pela realização dos mesmos. $^{7}$

Um comentário de Durkheim sobre a Revolução Francesa, os princípios que a inspiraram e as festas cívicas instituídas para mantê-los vivos evidencia a dimensão de sua preocupação com a transformação social. Em suas palavras, "se a instituição desapareceu rapidamente foi porque a fé revolucionária durou pouco; foi porque as decep̧ões e o desânimo substituiram rapidamente o primeiro momento de entusiasmo. Mas ainda que a obra tenha abortado, ela nos permite imaginar que cedo ou tarde ela seria retomada. Não bá evangelhos que sejam imortais e não bá raqão para se acreditar que a bumanidade seja doravante incapaz de conceber outros" (FEVR, p. 506).

7 A este respeito, Filloux ressalta a necessidade de distinguir, no pensamento de Durkheim, desenvolvimento, entendido como evolução natural e contínua da sociedade, e transformação, referida às mudanças tributadas à vontade e à ação individuais. Considerando os limites à ação dos indivíduos e a "finção ativa da ciência social" na transformação da sociedade em Durkheim, o autor interpreta que, na opinião deste, a transformação é "apenas um momento do desenvolvimento" (CSA, "Introdução", p. 43-4).

Temáticas, Campinas, 5(9/10):23-66, jan./dez. 1997 
A dimensão da transformação e da atuação dos indivíduos fica freqüentemente subsumida, nas interpretações do pensamento durkheimiano, pela prevalência da noção de sociedade em evolução natural. É possível, entretanto, considerando sua reflexão sobre a eficácia dos universos ideológicos na transformação social, uma leitura que, sem situar Durkheim como defensor do espírito revolucionário, reconheça em seu pensamento o verdadeiro sentido, por ele explicitado no Prefácio da segunda edição de As Regras do Método Sociológico, do preceito metodológico relativo ao tratamento dos fatos sociais como coisas, assim como da relação sociedade-indivíduo (pode-se ler "público-privado", discussão tão atual) num momento de constituição da sociologia, em que a delimitação de um campo novo de estudo não se esbarrou apenas na filosofia, mas também na psicologia, no que diz respeito à ocupação de um espaço científico e um espaço institucional-acadêmico na França do final do século XIX.

Neste contexto, a ênfase na sociedade e em sua superioridade moral não impede a consideração de que os indivíduos têm o dever de "lutar contra idéias morais que sabemos antiquadas, meros resquícios contra os quais a negação de sua validade pareça-nos ser o meio mais eficaz, não só no campo teórico mas também no terreno prático dos fatos" (SF, p. 92-3), antes mesmo que a sociologia, em constituição, produzisse os conhecimentos que permitiriam o julgamento da moral. Neste, como em outros contextos de sua obra, fica estabelecida a relação entre ciência, explicação desinteressada do que foi e do que é, e arte, ação política.

Penso ser correto dizer que a persistente busca de rigor e objetividade científicos não expulsou o dever-ser da sociedade do pensamento de Durkheim. Afinal, lembrando apenas mais um exemplo, o que significa a distinção dos fatos normais, "os que são como deviam ser", e patológicos, "os que deviam ser diferentes do que são"? 


\section{SOCIOLOGIA E EDUCAÇÃO: A CONSTRUÇÃO DO ESPÍRITO NACIONAL}

“(...) as práticas cducativas (...) são fatos de uma mesma espécie, competem à mesma categoria lógica; podem servir, portanto, de objeto de uma só c mesma ciência, a ciência da educação" (ES, p. 73).

Como Durkheim, cientista social e educador, numa sociedade anômica, que atravessa uma "fase de transição e de mediocridade moral", em que "os antigos deuses envelhecem ou morrem, e não nasceram outros" (FEVR, p. 505), pensou a educação, um século atrás? Quais aspectos de sua reflexão permanecem presentes, atuais e/ou reclamando atualização? Como, enfim, se justifica situar Durkheim no binômio "modernidade e educação"?

A epígrafe e as próprias questões já indicam a perspectiva em que, neste ensaio, se coloca o pensamento pedagógico durkheimiano: nos quadros da sociologia científica, em cuja construção Durkheim se empenhou, para dar conta da explicação do objeto - a sociedade em sua problematicidade - que a reclamava. Desta perspectiva, as preocupações de Durkheim com o fato educação se constituem em resultado e objetivo de suas formulações teórico-metodológicas, pelas quais o educador e cidadão se une ao cientista social, elegendo a educação como eixo temático de sua sociologia.

A compreensão desta escolha ele próprio nos oferece, quando estabelece, em As Regras do Método Sociológico, como critério da experimentação em sociologia a busca dos fatos de maior valor explicativo. Assim, em $A$ Divisão do Trabalho Social Durkheim se atém à explicação da transição de um tipo de solidariedade ao outro na constituição e diferenciação do indivíduo, na e pela sociedade, que se diferencia e se complexifica. Os efeitos do desenvolvimento de formas anômicas da divisão do trabalho são teorizados, e, a partir da classificação dos tipos de suicídio, a reflexão sobre o caráter patológico 
atribuído à elevação das taxas de alguns de seus tipos evidencia a correlação positiva destes com a forma assumida pelo desenvolvimento das atividades econômicas na sociedade moderna, após ter sistematizado, em As Regras..., o método de investigação da sociologia.

Nesta sistematização, transcende a filosofia e a metodologia positivistas de então pela crítica ao reducionismo na ciência social, no que se incluem aspectos de seu próprio trabalho, e argumenta em favor da necessidade e da possibilidade da experimentação em sociologia, cujos fenômenos de estudo se distinguem daqueles tratados pelas demais ciências apenas no que se refere ao maior grau de complexidade dos primeiros, o que "pode muito bem significar que o emprego do raciocínio experimental em sociologia oferece mais dificuldades ainda que em outras ciências; mas não se vê por que seria radicalmente impossivel" (RMS, p. 110). E, considerando as múltiplas e intrincadas relações entre os fenômenos que dificultam a determinação de suas causas e efeitos, defende o uso do método das variações concomitantes em sociologia, de modo a combinar observação, dedução e comparações na elucidação das relações causais, chamando a atenção para o fato de que neste caso os resultados deverão ser objeto de interpretação (RMS, p. 115).

Ao estudo das instituições deve-se aplicar, portanto, um raciocínio conceitual interpretativo, instrumentado pela história e pelo método comparativo, com vistas à explicação de sua gênese, das múltiplas condições e variações do meio social que as geraram, em relação às variações que apresentaram em seu desenvolvimento, assim como em sua correspondência às necessidades gerais do organismo social. Tal é o exemplo que Durkheim nos oferece, ao analisar a evolução pedagógica da França, articulando aspectos econômicos, políticos e socioculturais, com destaque às energias ou forças sociais acumuladas que, podendo se liberar das questões relativas à conservação da vida, se aplicam nos ideais coletivos que mobilizam os homens, multiplicam as interações sociais, 
criam "momentos de efervescência" nos quais se efetiva um impulso do processo civilizatório, com repercussão nos progressos do ensino ${ }^{8}$.

A compreensão da importância dos ideais na "ordem social, enquanto processo de transformação e desenvolvimento" (FILLOUX, 1975, p. 44) foi apreendida por Durkheim no sentido da eficácia da religião, como força de coesão social. A ausência desta coesão na sociedade moderna produz uma sociedade anômica, contrária à natureza da divisão do trabalho e à harmonia social, condição e situação que conduzem os homens em dois sentidos contraditórios, sob a forma de apelos constitutivos de sua natureza, e se expressam na obra As Formas Elementares da Vida Religiosa, encaminhando Durkheim, em face do processo de laicização e de insuficiência crescente do poder de unificação dos indivíduos pela religião, para a explicação científica da educação, fato social.

A escola, instituição específica de educação, cuja função consiste em transformar os indivíduos de cada geração em seres sociais, pode então ser vista como um laboratório no qual teoria e prática se unificam na busca da solidariedade e da harmonia, numa sociedade que se divide orientada por ideais conflitantes, divergentes, expressão da rapidez em que se dera a transição de um tipo de solidariedade ao outro, repercutindo na saúde da vida social, afetada por uma defasagem entre os processos de diferenciação e integração.

Valores, crenças e tradições que soldam os elementos sociais perderam sua força na nova estrutura social, e esta, em sua constituição, não gerara ainda a preponderância de outros capazes de lhe dar sustentação. Estes se anunciam, estão em emergência. $O$ estudo

\footnotetext{
${ }^{8}$ Segundo Lukes (1977), "o esquema esplanatório" de Durkheim em A Evolução Pedagógica na França "não é monocausal, nem unilateral" (p. 381). Giddens (1978) ressalta a este respeito " importância da bistória para a explaniação sociológica" nesta obra, em que Durkheim "tentou mostrar que a teoria e a prática da educação estavam passando por um processo de mudança que refletia o processo experimentado pela sociedade em geral" (p. 56).
} 
científico da moral evidenciaria os valores que a nova ordem reclamava, tornando possível a determinação dos fins e meios da educação dos indivíduos nas novas maneiras de ser, pensar, sentir e agir. A escola surgia, então, como campo de ação singular, no processo de socialização das instituições modernas fundamentado na ciência da moral, objetivo primeiro de uma sociologia que se constrói como aquela que "veria no espirito de disciplina a condição essencial de toda vida em comum" (RMS, p. 108).

O pensamento durkheimiano, no qual a questão moral é o centro e o horizonte, se desdobrará numa teoria da ação em que, se se estabelece uma distinção entre ciência, expressão desinteressada do real, e arte, ação política, se define, no mesmo contexto, a passagem da explicação científica à ação normatizadora. 'Mas, diz-se, se a ciência prevê, ela não comanda. É verdade; ela diz-nos somente o que é necessário à vida. Mas, supondo que o homem queira viver, como não ver que uma operação muito simples transforma imediatamente as leis que ela estabelece em normas de conduta? Sem duivida, transforma-se então em arte; mas, a passagem de uma a outra faz-se sem solução de continuidade" (DTS, v. 1, p. 46).

Neste sentido, a sociologia durkheimiana se articula com a política educacional da Terceira República, em cujo contexto uma ampla reforma educacional é empreendida, visando à consolidação do sistema público de ensino em seus três níveis e a adequação de cada um destes ao papel que lhes cabe na construção da nação: educar o homem racional e moral requerido pela nova ordem. É como professor universitário, na Faculdade de Letras de Bodeaux e, posteriormente, na Sorbonne, que Durkheim se situa como sociólogo e como pedagogo no esforço de profissionalização dos professores. Ressalte-se que, desde 1887, e ao longo de quase trinta anos, Durkheim divide seu tempo entre as atividades de cientista social e a docência, que incluía as aulas de ciência da educação nos cursos de formação de professores. Antes disto, ao optar pela docência, em 1882, segundo sugestivo depoimento de 
Georges Davy, Durkheim "se sente chamado a desempenhar, para além da prática do ensino, (...) um papel na reconstrução da França ferida pela derrota" (apud LACROIX, 1984, p. 34).

Esta vontade política se mantém na atividade científica de Durkheim, na escolha de seus temas de investigação, e se manifesta em sua teoria e prática da educação. Convém lembrar aqui a interrogação sobre o valor em "se esforşar por conbecer o real, se o conbecimento adquirido não nos pode servir em nada na vida prática" (RMS, p. 42), cuja resposta consiste em reafirmar o ideal de rigor e objetividade, pressuposto no método sociológico, como possibilidade e garantia de "reivindicar os direitos da razão sem cair na ideologia" (RMS, p. 42), e assim, com conhecimento de causa, esclarecer a prática, o que permitirá "não (...) mais (...) perseguir desesperadamente um fim que foge à medida que se avança, mas de trabalbar com regular perseverança para manter o estado normal, restabelecendo-o se está perturbado, reencontrando suas condições se vierem a mudar" (RMS, p. 65).

Perseverança, de fato, é o que se evidencia nos escritos e atividades pedagógicos de Durkheim, que, em sua aula de abertura do curso sobre o ensino secundário na França, em 1902, afirma seu interesse de longa data em relação a este nível de ensino, ao qual se aliava a urgência da questão posta pela reforma anunciada para o mesmo. Declara-se então preparado para tratar do tema, e assume, como factível de execução, o ideal reformador, assim como se coloca na posição de quem está pensando para o mundo, a partir de uma sociedade que se adiantara no processo de autoconsciência ( $E M$, p. 237).

Seu interesse pela questão pedagógica é amplo e revelador da sintonia entre ensino e pesquisa sociológica da educação. Os temas estudados abrangem a educação intelectual, em relação à qual discute disposições mentais do educando e componentes curriculares?; a

\footnotetext{
${ }^{9}$ Ver a respeito: CHERKAOUI, 1978.
} 
educação moral, sobre a qual estabelece os elementos da moralidade, detalhando a questão da constituição destes no educando; a história da educação e das doutrinas pedagógicas, consideradas "documentos acerca do espirito do tempo" (ES, p. 130).

Tais estudos permitem ao sociólogo colocar como elemento de formação de professores o conhecimento científico da realidade na qual iriam atuar como profissionais, contribuindo para o enfrentamento da circularidade negativa entre educação e sociedade, o que assim se expressa em O Suicidio: "dado que cada nova geração é educada pela anterior, seria necessário que esta se corrigisse antes de empreender a correção da segunda" ( $\mathrm{p}$. 375). As profundas mudanças ocorridas nas sociedades européias requeriam mudanças igualmente profundas no ensino e, conseqüentemente, um trabalho que articulasse as funções dos professores com as funções da sociedade.

Para isto, uma cultura pedagógica não pode absolutamente prescindir de uma cultura sociológica. É a esta cultura que Durkheim visa com seus cursos sobre a educação moral na escola primária e o curso sobre a evolução do ensino secundário na França. Em ambos, trata da educação moral e intelectual, empreendendo uma síntese de sua sociologia moral - no que revela aquela motivação de que nos fala $G$. Davy, na efetivação da relação entre ciência e arte pela intermediação da pedagogia -, e explicita a dimensão política da educação, em sua concreticidade real e na sua representação teórica.

A distinção entre os termos "ciência", "pedagogia" e "educação" é inicial em L'Éducation Morale. Ao fazê-la, Durkheim se anuncia como pedagogo (p. 1). A sociologia - ciência da educação, pois a educação, fenômeno social que é, se explica pela sociedade - fundamenta a pedagogia, fornecendo-lhe a explicação desinteressada do que é a educação em termos de sua gênese, causas e funções, e a segunda, entendida como reflexão metódica da educação, informa a prática do professor, seu saberfazer, a arte de educar. 
Desta forma, a reflexão é afirmada como atitude e prática do educador, pois somente ela, por ser "inimiga da rotina", pode manter o professor em "estado de alerta" e, assim, dotá-lo da flexibilidade que "permite variar, evoluir, adaptar-se à diversidade das circunstâncias e dos meios" (EPF, p. 12). Mas também a "fé pedagógica" é considerada elemento necessário ao trabalho do educador, uma "missão", numa analogia com o trabalho do sacerdote, ao qual, no contexto de secularização da moral e no que diz respeito à educação, substituiria. Assim, se a autoridade do sacerdote tem origem e se fortalece na fé em relação à palavra revelada, da qual é o intérprete, o professor, tradutor do espírito de sua pátria, deve fundar sua autoridade em sua fé na grandeza de sua missão de criar o homem novo reclamado pela sociedade.

Mas é como homem de ciência que Durkheim se propõe abordar o tema, ou seja, utilizando o método de investigação das ciências históricas e sociais, único que possibilita um conhecimento das coisas por dentro delas, na sua gênese e nas carências que elas atendem. " $A$ referência que faģo à fé pedagógica não significa que tenbo a intenção de pregar alguma. Estou aqui como homem de ciência. Mas acredito que a ciência das realidades bumanas pode orientar proveitosamente a conduta bumana" (ES, p. 129).

Este conhecimento do ensino secundário como um todo permitiria aos futuros professores uma reflexão informada pela ciência, resultando num trabalho de cooperação que, estendendo-se por toda a vida, deveria ter início na universidade ${ }^{10}$, na qual se preparam para

${ }^{10}$ Ao enfatizar a necessidade da reflexão do corpo de professores sobre a atividade global para a qual cada um realiza uma parte, visando à unidade da mesma, Durkheim chama a atenção para um fato que ainda hoje nos preocupa: a fragmentação do trabalho pedagógico de formação de professores na universidade, na qual os futuros professores fazem os seus estudos em grupos que não se encontram para uma visão de conjunto da função que vão desempenhar, ou para uma reflexão da educação, enquanto fenômeno social e como uma "missão comum", o que se reproduz na fragmentação do trabalho pedagógico, no ensino secundário (ES, p. 104). Outro aspecto discutido por Durkheim 
formar uma opinião do dever-ser da cultura, para dar vida à reforma do ensino e à escola, porque conhecedores de seus elementos constitutivos. Pois a escola, como todo sistema, é formada pelo instituído, a tradição, sob que se constitui toda uma vida, idéias nascidas no interior do sistema que o forçam a transformar-se. Estas idéias são o instituinte, tendências que buscam se afirmar e que devem ser identificadas em suas relações com a realidade que lhes dá origem e promovidas (ES, p. 122).

A compreensão da modernidade como "um movimento que arrasta $o$ mundo que nos rodeia e nos arrasta com ele" (ES, p. 112) reforça a convicção de que à sociologia cabe a explicação da educação que, neste e por este movimento, a sociedade estava a exigir. Porque a educação é sempre referida a um homem situado e datado, vivendo concretamente numa sociedade determinada, num momento determinado de sua evolução, compete à sociologia a determinação de seus fins. A psicologia estabeleceria os meios para atingi-los, naquilo que diz respeito às características psicológicas específicas da criança, pois, considerando a natureza social dos meios empregados na educação, nestes também cabe à sociologia matéria de decisão. Esta fornece, pois, ao educador, "um

(EPF, cap. 27), o desenvolvimento das categorias do pensamento, que significa pensar conforme o pensamento científico, pode também ser transferido para as discussões contemporâneas sobre a formação de professores em nossa universidade. Durkheim argumenta em favor do ensino da metodologia das ciências pelo próprio professor da área, e não nas aulas de filosofia (trazendo para a discussão de hoje, não nas faculdades de educação), uma vez que aprender a ciência não se limita a conhecer os resultados a que as mesmas chegaram, mas assimilar os processos mentais e métodos que permitiram esses resultados, o que só pode ser ensinado por aqueles que os tenham vivido. Esta é uma dicussão presente hoje na universidade brasileira, envolvendo professores das faculdades de educação e dos institutos básicos, resultando em soluções que incluem remanejamento de professores e disciplinas, a constituição de comissões mistas de professores das diferentes unidades que oferecem os cursos de licenciaturas, com vistas a uma coordenação conjunta de cada curso, e mudanças curriculares. 
corpo de idéias diretrizes", dando sustentação e significado ao seu trabalho, prendendo-o ao mesmo ( $E S$, p.122). A relação de dependência muito mais estreita da pedagogia com a sociologia do que com qualquer outra ciência consiste, assim, no corolário do "axioma fundamental de toda especulação pedagógica" expresso na afirmação da "natureza eminentemente social da educação, seja por suas origens, seja por suas funções" (ES, p. 92).

O conhecimento da educação enquanto fato social deve ser buscado na história do ensino, "a melhor das escolas pedagógicas" (EPF, p. 16), em sua gênese e nas modificações por ele sofridas em termos da organização escolar, das leis e regulamentos que disciplinaram o seu funcionamento, do ideal pedagógico de formação do homem em cada momento, em sua relação com as forças sociais presentes.

A oposição, apenas aparente, entre o velho e o novo é descartada, pois o presente, não sendo um em-si, mas o prolongamento do passado, acréscimo gradativo dos elementos deste, em que se abriga grande parte do seu significado, não pode dele se abstrair. Em face da imediatez envolvente do presente, que direciona a visão somente para aquilo que ditam as vontades pessoais - o que é necessário, mas unilateral -, o conhecimento da história da educação se revela como um "contrapeso", permitindo evitar erros no futuro, corrigir erros do passado que se mantêm influentes, resgatar acertos que sucumbiram no "ardor da luta pelo novo", que, entretanto, ainda se demonstram válidos nas condições presentes. É necessário fazer este inventário, pois, "ao mesmo tempo que nos fornece um melhor conbecimento do presente, nos permitirá a revisão do nosso passado, colocando em evidência erros de que precisamos tomar consciência, pois deles somos berdeiros" (EPF, p. 24).

Reconstruir o ensino secundário, em sua gênese, atende, assim, a um duplo objetivo: trazer a discussão para o que é fundamental, a questão sobre que espécies de realidades devem se constituir em objetos sobre os quais as mentes devem se aplicar, e retirar de cada momento da 
evolução deste ensino as aquisições que, comparadas as condições passadas e presentes, se evidenciem como ainda válidas, em face das necessidades atuais. A finalidade última é pensar, no contexto da reforma, como o ensino deve se organizar na busca de seu objetivo: criar o ser social que, dada a complexidade do mundo moderno, não pode prescindir da reflexão.

Neste sentido, o princípio de unidade de direção, inerente ao ensino cristão desde suas origens, e pelo qual a escola se constitui num meio de formação, ao mesmo tempo intelectual e moral, mantém-se válido para a educação intelectual, no contexto de secularização da moral, pois também neste a educação não tem por objetivo adornar a mente com os conhecimentos, mas sim formar o espírito, constituir na criança um estado interior profundo que a oriente e direcione num caminho definido, não só na infância, mas por toda a vida.

Deduzida da história, a concepção da escola como "um feixe de forças intelectuais", constituído pela geração instruída concentrada para instruir a seguinte, sustenta a conclusão de que o ensino que nela se realiza " $e$ tanto mais elevado quanto mais concentrado for este feixe" (EPF, p. 137), pois desta concentração resulta a constituição da escola como um meio moral, no qual os professores de diferentes áreas se unem no objetivo que dá sentido à sua prática: formar o espírito do educando, "acordar a mente para a reflexão, exercitar e fortalecer as faculdades especulativas (...) desenvolver a aptidão para uma correta apreensão da realidade bumana $e$ natural" (EPF, p. 361-2).

Assim, na pedagogia realista de Durkheim definem-se, como realidades sobre as quais se deve aprender a fazer idéias claras e distintas, implicadas nos atos de julgar, avaliar, raciocinar refletir, dois eixos curriculares: o que diz respeito à realidade do homem e o que se refere à realidade da natureza. $\mathrm{O}$ ensino humanístico e o científico se completam, concorrendo, ambos, para a realização do objetivo presente na 
cosmologia religiosa, desde a religião mais primitiva: fornecer ao homem os meios lógicos de distinguir as coisas do universo do qual é parte, de formar deste uma concepção e nele se situar, pois, para substituir o ensino religioso, a escola laica deve dar conta da função que aquele vinha cumprindo na história das sociedades.

Os conteúdos do primeiro eixo se encontram na história da civilização, num estudo que se caracterize por evidenciar o homem em sua complexidade. Grécia e Roma são mantidas como exemplares, e na história moderna o destaque vai para a história nacional. Neste eixo também se inclui o estudo das literaturas, que é "onde se fixa o principal das civilizações" (EPF, p. 380). Já o segundo eixo corresponde às ciências físicas e biológicas. Um terceiro eixo, constituído pelo ensino da língua e da gramática, situa-se na base dos anteriores, compondo-se assim a tripla cultura que, no ensino secundário, determina objetos e meio de aplicação da mente para que nela se desenvolvam as categorias lógicas do entendimento humano, constitutivas da mente e da vontade dos educandos. Conteúdos e métodos de ensino são vistos, pois, como meios de formação intelectual e moral, e não como fins em si mesmos.

A discussão relativa à predominância no ensino secundário seja das letras, seja das ciências, oposição destituída de sentido, não toca no problema fundamental deste ensino. $O$ pensamento durkheimiano, ao voltar-se para a explicitação da dimensão social da educação, se orienta para a busca da dimensão educativa do ensino primário e secundário, a amplitude de seu alcance, que não diz respeito ao objetivo utilitário de preparar para as atividades industriais e comerciais, mas tem como fim último a vida moral, o que define a sua natureza fundamentalmente articuladora da cidadania e moral republicana, formadora e sustentáculo de uma sociedade civil forte, compatível com o significado cultural e político da 1 çça de então na Europa e no mundo.

Derivada da concepção de sociedade e do indivíduo, assim como das relações entre ambos, uma definição contextual de educação, 
fundamentada na autoridade e ascendência moral da sociedade, situa a escola como instituição de fundamental importância no contexto de perturbações decorrentes do processo de modernização e de expansão do capitalismo e na laicização da cultura que lhe é inerente, processo que determina, a um só tempo, a dupla função da educação (leia-se escola como meio moral), com seus fins relativos à educação moral e à educação intelectual, indissociáveis, na edificação de indivíduos partícipes da sociedade, que "não pode abandonar as categorias [de pensamento] ao livre arbitrio dos particulares sem se abandonar a si própria" (FEVR, p. 46). Nesta definição, a educação consiste "na ação exercida, pelas gerações adultas, sobre as gerações que não se encontram ainda amadurecidas para a vida social; tem por objeto suscitar e desenvolver, na criança, certo número de estados físicos, intelectuais e morais, reclamados pela sociedade politica, em seu conjunto, e pelo meio especial ao qual ela é, particularmente, destinada" (ES, p. 51).

Esta definição suscita a questão da liberdade e autonomia do indivíduo, valores fundamentais da moral individualista, característica da sociedade moderna, cuja importância o próprio Durkheim defende. Para ele, entretanto, a oposição entre liberdade e autoridade é desprovida de sentido, pois estes dois termos, na verdade, são correlatos. " $A$ liberdade é filha da autoridade bem compreendida. Porque ser livre, não é fazer o que se queira; $e$ ser-se senhor de si, saber agir pela rąão praticando o dever" (ES, p. 68). É função da educação criar o ser moral e intelectual que tal concepção de liberdade supõe.

A educação forma a criança à semelhança da sociedade, nela construindo as bases de receptividade dos sentimentos, idéias e crenças, dos conteúdos das representações coletivas, da alma psíquica da sociedade. Tal é sua função homogeneizadora, na qual Durkheim está particularmente interessado e para a qual "convém reservar o nome de educação" (ES, p. 42), pois inculca em todos os membros da sociedade uma base comum que define um povo como sendo ele mesmo. 
Assim, reforçando similitudes, segundo uma hierarquia de valores estabelecida pela sociedade, e diferenciando os indivíduos conforme $o$ meio social, a educação escolar sobrepõe, ao ser que nasce egoísta, o ser social de que a sociedade precisa, para a cooperação de todos na obra comum. Esta é a dupla função que a sociedade impõe à educação, uma vez que "nada bá na nossa natureza congênita que nos predisponba a tornar-nos, necessariamente, servidores da divindade, ou de simbolos da sociedade, a render-lhes culto, a nos privarmos em seu proveito ou em sua bonra" (ES, p. 102).

Esta concepção ressoa os estudos sobre a religião, nos quais o princípio do sagrado, elemento essencial da religião, em geral, "outra coisa não é senão a sociedade bipostasiada" (FEVR, p. 416), e ratifica a divisão intrínseca da educação ${ }^{11}$ instituída pela burguesia, teorizada em seus primórdios por Comenius. Esta divisão permanece ainda hoje na seletividade pela qual a escola reproduz a divisão da sociedade, o que ganha expressão, em nossos dias, nas teorias de Bourdieu (cf. ORTIZ, 1983). Por meio do ensino elementar, comum a todos, forma-se a base a partir da qual a nova geração se divide entre o ensino secundário, préuniversitário, e o ensino técnico e industrial. Preparam-se assim os quadros sociais para as funções do pensamento e das atividades práticas. Quer na função homogeneizadora, quer na diferenciadora, a educação consiste, pois, na "socialização metódica de cada gerafãa" (ES, p. 102), como o exigem a divisão do trabalho social e a cooperação que esta supõe, na sociedade da solidariedade orgânica.

${ }^{11}$ Durkheim admite como moralmente injustificável esta ratificação das condições sociais de nascimento pela educação. Considera, entretanto, que, ainda que não houvesse esta determinação de alocação social desde o nascimento, a função diferenciadora da educação persistiria, pois a sociedade necessita dividir entre os seus membros as diferentes funções, e lembra que igualdade na educação só pode existir na sociedade primitiva, onde quase inexiste diferenciação (ES, p. 95-6). 
A educação consiste, pois, na união de dois termos antitéticos: personalidade, tudo aquilo que faz do homem uma pessoa humana, que "faz dele um homem, e não tal homem" (FEVR, p. 331), que o eleva acima de sua própria realidade empírica egoísta, voltando-o para as ações e fins coletivos, impessoais, e individualidade, pois não existe sociedade sem indivíduos associados, e esta é "tanto mais rica quanto mais numerosos e diferentes forem uns dos outros" (FEVR, p. 333), em cooperação na divisão do trabalho social. $O$ fator individual é, pois, condição do fator impessoal que faz do indivíduo um ser social. Entretanto, como tudo que recebemos da sociedade é comum a todos os seus membros, "longe está (...) de sermos mais pessoais, quanto mais individualizados. Os dois termos não são de nenbuma forma sinônimos: em certo sentido eles se opõem mais do que se implicam" (FEVR, p. 333).

É possível ler a ênfase na relação sociedade-indivíduo, personalidade-individualidade, como expressão da relação públicoprivado, o que confere à reflexão da educação, inscrita na ordem dos valores e, portanto, da ética, caráter de extrema atualidade. Em sua essência, os problemas enfrentados hoje pelas sociedades fundadas no individualismo não diferem daqueles sobre os quais Durkheim fez incidir sua reflexão. Eles se desdobram, se aprofundam, se elevam a patamares superiores de complexidade, o que mantém a educação como um desafio permanente à reflexão, do qual Durkheim, em seu tempo, não se omitiu.

É claro que sua reflexão se dá nos quadros da nação. Refere-se, em última instância, ao enfraquecimento da sociabilidade dos franceses, atribuído ao processo de unificação da nação iniciado pela monarquia e consumado pela Revolução Francesa. Os elementos da moralidade, e sua relação com a educação intelectual, se inscrevem na preocupação com os resultados do processo de individualização, que "faz com que a vida coletiva perca a sua vivacidade". Busca, ao estabelecer a inculcação do espírito de disciplina, de adesão ao grupo e da inteligência da moral como objetivos da educação elementar, na transição do século passado para o atual, uma 
sociabilidade moderna, demonstrando a clareza de sua percepção de que no novo patamar de organização da sociedade "deve-se necessariamente lutar contra todas as formas de particularismo, comunal, provincial e corporativo" (EM, p. 200). Por isso, na escola, "todo o problema consiste em aproveitar a associafão em que se encontram forçosamente as crianças numa mesma sala de aula para fazế-las tomarem gosto por uma vida coletiva mais extensa e impessoal do que aquela com a qual elas estão habituadas" (EM, p. 203). Trata-se, portanto, de fazer com que as crianças se sintam como um grupo, e neste reconfortadas, a fim de que aprendam a dizer nós. É objetivo de trabalho do professor "ensinar a criança a fruir deste prazer, de obrigá-la a contrair a necessidade do mesmo" (EM, p. 204), para o que são sugeridos situações e meios, visando à constituição do espírito de disciplina, à aquisição do sentimento de que o indivíduo, como parte de um todo, é, necessariamente, menor do que este. ${ }^{12}$

Desta perspectiva, a disciplina é boa em si mesma. A vida organizada não pode dela prescindir. Em As Regras do Método Sociológico, a disciplina se explica pela natureza sui generis da sociedade, que, sendo superior ao indivíduo, porque produto coletivo, coage-o, não por artifício ou convenção criados pelo homem, mas por "força natural" que "brota das entranbas da realidade", "produto natural de causas dadas", diante da qual o indivíduo se inclina (p. 107). Em L'Éducation Morale, o espírito de disciplina, primeiro elemento da moralidade, é defendido não só porque útil e necessário ao indivíduo, mas porque somente através dele é que a natureza humana se realiza no homem, que, não sendo isolado, se depara com limites que lhes são impostos. A necessidade desses limites, por sua

12 Uma análise minuciosa dos elementos da moralidade constitutivos do projeto durkheimiano de educação é feita por Heloísa R. Fernandes (1994), que elege a obra de Durkheim para "analisar o dispositivo que ali é construido e justificado de modo a sustentar a tese de que esse dispositivo não está comprometido com o ideal de autonomia de cidadãos livres, responsáveis e criadores, mas que, ao contrário, é um substituto do dispositivo da moralização cristã, com efeitos similares" (p. 15). 
vez, e sua relação com a felicidade do indivíduo são consideradas em $O$ Suicídio, em que se apresentam elementos de reforma intelectual e moral e de regulamentação social que resultem no desenvolvimento normal da solidariedade orgânica.

A autoridade das regras morais, que lhes garante a eficácia e que por isto tem de ser preservada, não deve, entretanto, subtraí-las à discussão e à reflexão, pois isto seria a negação da dignidade e do respeito ao indivíduo, cuja adesão às regras se funda na inteligibilidade das mesmas. Além disso, sendo estas regras relativas ao tempo e ao espaço, categorias socialmente produzidas, não são hoje, em sua totalidade, o que foram ontem, e amanhã terão se modificado junto com a sociedade, em seu dinamismo.

A idéia de que a moral não é imutável - pois, sendo viva, "evolui e se transforma sem cessar" pela emergência de "idéias e aspirações novas que brotam $e$ preparam modificações e mesmo revoluções profundas da moral existente" (IM, p. 316) - acompanha Durkheim até o trabalho, inacabado, do qual se ocupou nos últimos dias de vida. Neste, ele é explícito quanto ao "papel do moralista [que] é preparar estas transformações necessárias". O moralista, porque "(...) não se deixa deter pela moral instituida (...), pode fazer uma obra original, trabalhar no novo", exprimindo de maneira refletida "as correntes que marcam a sociedade e entre as quais se dividem os espiritos" (IM, p. 316). A especulação moral tem, pois, um caráter misto: ao mesmo tempo "científica, visa os fins práticos (...) é obra de pensamento e de reflexão; mas ela é também um elemento da vida (...) ao mesmo tempo arte e ciência", o que não lhe é exclusivo, pois "também a pedagogia, a politica têm a mesma característica" (IM, p. 317).

Determinando fins e meios da educação na escola, que se reformava, Durkheim transcende o compromisso do sociólogo, nele inseparável do educador e pedagogo, interroga a educação em seu sentido e valor, busca em sua história o que permanece, o que muda, preocupando-se com os porquês e o como, explicita os fundamentos da educação, a partir da sociologia que se faz moral e ética, ao pensar os 
costumes e ao interrogar o ethos, operação em que a consciência moral coletiva é, ao mesmo tempo, o ponto de partida e o ponto de chegada. Reflexão e ação, ciência e arte. Filosofia e sociologia se unem e se completam na tradução da educação, em seu ser eminentemente moral, como "medianeira da cultura" ${ }^{13}$ e como força social, na construção da nação, na reedificação do espírito do povo francês, no aperfeiçoamento do cosmopolitismo que, segundo Durkheim, o caracteriza.

\section{SOCIOLOGIA E EDUCAÇÃO: DA APREENSÃO DO NACIONAL AO COSMOPOLITISMO}

“(...) não existe vida nacional que não seja dominada por uma vida coletiva de natureza internacional. $\grave{A}$ medida que se avança na história, esses agrupamentos internacionais assumem maior importância c extensão" (FEVR, p. 504).

Por que Durkheim, ao conceber a sociologia como a ciência da educação, não designa um ramo específico na sua fisiologia social para a educação?

No Brasil da década de 40, Fernando de Azevedo cuida desta especificação em sua Sociologia Educacional, saudada por Roger Bastide como o desdobramento da sociologia da educação da qual Durkheim "nos havia dado o prefácio" (apud AZEVEDO, s/d., p. 2). Ao considerar a educação como processo social geral, Azevedo chama a atenção para o

\footnotetext{
${ }^{13}$ A expressão é de Moacir Laterza e Terezinha A. Rios (1971). É freqüente a afirmação sobre a característica filosófica do pensamento sociológico de Durkheim que tinha como formação básica a filosofia. Segundo Raymond Aron (1987, p. 359), para quem "Durkbeim tinha um temperamento filosófico, (...) dizer que uma doutrina sociológica contém elementos filosóficos não é depreciá-la". Na persrpectiva deste ensaio, a interrogação filosófica é que, com certeza, confere riqueza e amplitude de alcance ao pensamento sociológico de Durkheim.
} 
fato de que a sociologia educacional de Durkheim não se restringe às questões relativas à instituição escolar. Em sua interpretação, "se Durkheim afirma a sociologia como ciência das instituigões não é certamente por julgar que fossem os únicos fatos sociais a estudar, mas por oferecerem, as instituições, pelo seu caráter mais concreto e estático, melhor campo de investigação" (AZEVEDO, s/d, p. 86).

É necessário acrescentar, porém, a importância de que se reveste a constituição, no final do século XIX, do sistema público de ensino, cujo ápice é a Universidade de França, criada por decreto de março de 1808. Durkheim, enaltecendo o fato como "o grande acontecimento que domina toda a bistória escolar do século XIX” (EPF, p. 351), atribui sua causa não ao gênio de Napoleão, mas às necessidades sociais que antecedem a Revolução Francesa. Estas necessidades, que expressam um ideal pedagógico, já haviam encontrado em La Chalotais ("Essai d’Éducation Nacionale", 1763) e Rolland d'Erceville (em relatório de 1768) os seus intérpretes, e, como forças que são, se concentram na escola pública do século XIX, a cuja organização Durkheim se entregou com entusiasmo, o que é compreensível se pensarmos que, em sua perspectiva, este acontecimento pode ser lido como a materialização das representações coletivas, categoria fundamental de sua sociologia, na qual educação e moral constituem uma unidade.

Esta última afirmação requer uma explicação que, da perspectiva deste ensaio, aponta na direção de uma interpretação do pensamento educacional durkheim: ano, para além da instituição escola e do espaço da nação, ainda que estes tenham constituído, sem dúvida, frentes de atuação teórica e prática fundamentais, o que não pode impedir o reconhecimento de que Durkheim não se preocupou somente com a educação das novas gerações, na instituição escolar, na França da Terceira República.

Como cidadão atuante e como intelectual, Durkheim, que defendia a incompatibilidade entre as atividades de pensamento e aquelas 
ligadas à representação política, manteve uma atitude e um comportamento políticos, no sentido amplo do termo, isto é, no sentido em que ele é referido à organização da pólis, da cidade, da República, do que se depreende, necessariamente, uma concepção global da educação que não pode se restringir ao espaço escolar, mas tende a abarcar, em sua amplitude, a relação indivíduo-sociedade, assim como as relações das sociedades entre si, em seu movimento de expansão capitalista que logo abriria o mundo à guerra.

É verdade que se pode perceber no pensamento de Durkheim a interrogação permanente na busca de compreender e explicar a res publica e, nesta, as condições para o consenso. Neste sentido, ao argumentar contra a participação dos intelectuais na política, defendia a atuação destes, definidos como "educadores e conselheiros" (CSA, p. 252), no esclarecimento da opinião pública "dividida e perturbada" de seu tempo, o que seria feito através do livro, da conferência, dos trabalhos de educação popular (CSA, p. 252). Foi como intelectual, educador e cientista social que Durkheim exercitou a prática política na busca da justiça e do consenso na República que se organizava. Assim, a educação do republicano deveria começar desde a segunda infância, na escola primária, sob a égide do Estado. E esta, como vimos, constitui, para ele, verdadeiramente, o que se deve designar por educação.

Mas a educação também se situava no ensino técnico e no ensino de adultos, que, segundo Durkheim, deveriam ser atribuição das corporações profissionais, cuja reorganização ele defendia, pois as via como órgãos que constituiriam o substrato unificador das funções ou atividades econômicas difusas na sociedade, e que tinham, na sua concepção de sociedade orgânica, as funções relativas à educação, seja em sua face de instrução, seja em sentido social amplo, de unificação moral e, portanto, social dos indivíduos, enquanto cooperadores na vida coletiva. Ligando os indivíduos, a partir dos diversos ramos da atividade econômica, ao órgão central, o Estado, ao qual compete unificar o todo, 
as corporações se constituiriam em meio moral único para o "desenvolvimento de sentimentos e idéias sociais", pois, "qualquer que seja o local onde se encontrem" os indivíduos, a corporação está presente "para os enquadrar, os chamar ao dever, os amparar se necessário for" (OS, p. 381). Ora, isto significa dizer que educação em Durkheim é também a da classe operária, que tendia para o internacionalismo da luta de classes e em oposição ao grupo político constituído, isto é, à pátria.

Como vimos, Durkheim se ocupou da organização da escola pública em todos os níveis. Mas a ação política, em sentido amplo, envolveu ação e pensamento de Durkheim. Não é por acaso que para ele "a moral é mesmo de todas as partes da sociologia a que de preferência nos atrai e sobre a qual, em primeiro lugar, vamos nos debrugar" (CS A, p. 99), e não é sem razão que educação em Durkheim é moral. Esta última, ao lado do direito, da religião, da economia, da lingüística e da estética, compunha o conjunto da sua fisiologia social.

Como observa B. Lacroix, anteriormente a este detalhamento da fisiologia social a política é sugerida como um ramo específico da sociologia. Demonstrando sua tese de que o político está presente em toda a obra de Durkheim, o autor citado conclui que "o desaparecimento da sociologia politica como ramo individualizado da sociologia geral levava consigo o reconbecimento do dado capital segundo o qual a sociedade é politica de parte a parte" (LACROIX, 1984, p. 235)

Penso que esta conclusão se aplica também à ausência de designação, por Dur' 'reim, de um ramo específico para a educação em sua sociologia. A sociedade é educativa no seu todo e em suas partes, incluindo, além da escola, seu meio fundamental na sociedade moderna, a família, a religião, as corporações, a opinião pública, o trabalho. $O$ próprio Estado, cujo dever fundamental é "o de chamar o indivíduo à existência moral" ( $L S$, p. 64), é o grande educador e portador da legitimidade moral coletiva no espaço da nação. 
Pode-se pensar, assim, que educação é sobretudo o exercício da autoridade da sociedade sobre o indivíduo, poder que se exerce de forma difusa na sociedade primitiva, obrigando o indivíduo a buscar, desejando, tudo aquilo que o insere na vida coletiva, e que, com a evolução da sociedade, concentra as forças pelas quais se constitui, no século XIX, o sistema público de ensino, para garantir, na sociedade da solidariedade orgânica, que as novas gerações assimilem, internalizem o espírito nacional que esta solidariedade supõe. Espírito este que, inscrito nas representações coletivas, se materializa nos símbolos e emblemas produzidos para revivê-lo; na cultura escolar organizada, para cravá-lo, profundamente nas novas gerações e aí mantê-lo vivo; mas também, por exemplo, na organização do trabalho cooperativo, pois, "longe de ser desmantelada pelos progressos da especializąãa, a personalidade individual desenvolve-se com a divisão do trabalho" (DTS, v. 2, p. 201).

Diversas são, pois, as formas de socializar os indivíduos e manter a coesão e a cooperação sociais, numa sociedade que, não sendo estática, se desdobra e se transforma no caminhar em direção à sua forma superior: democrática, justa, civilizada, socializada.

A concentração destas forças na instituição escolar não as detém, pois, exclusivamente, em seu interior. Elas se manifestam também nas demais instituições sociais solidárias entre si e, no conjunto, solidárias com o organismo social. Deste processo resultam múltiplos apelos que obrigam os indivíduos a se diferenciar, se personalizar, se socializar, a reconhecer a superioridade do coletivo, em face do qual mantêm relação de dependência. Pensar que este processo pode se encerrar na instituição que se diferencia como centro do mesmo, e enquanto tal merecedora ou vítima do controle, do mando e do desmando daqueles que representam o poder na sociedade, é ignorar a possibilidade de pensar que, em Durkheim, como o poder, a educação continua difusa na sociedade, e esta, como um todo maior do que a escola por ela inventada, pode reproduzir a educação de que precisa em outras instâncias que não esta, 
eleita ontem como o deus da educação, mas da qual não se pode dizer que, amanhã, necessariamente, continuará a sê-lo. A sociedade pode escolher outro deus.

Poderíamos assim conjeturar que, para além do significado da educação freqüentemente lido em Durkheim, e por ele próprio didaticamente explicitado numa definição formal, a educação consiste no processo pelo qual os indivíduos aprendem a partilhar, comungar crenças e opiniões, maneiras de ser, pensar, sentir e agir em sociedade, a qual, em sua totalidade, se constitui em mestre maior, obrigando e atraindo os indivíduos, através de suas partes instituídas ou a instituir, conforme as necessidades reveladas pelo curso de seu funcionamento, no e do qual derivam múltiplas formas de submetimento consentido de seus membros, de todas as gerações, ao dever cotidiano de serem sociais, de elevarem-se acima de si mesmos, de serem solidários.

Educação pode ser entendida, portanto, como um amplo processo de socialização dos indivíduos, pelas forças coletivas, pelas representações coletivas, cuja eficácia se faz sentir por meio das instituições e órgãos que, no conjunto, compõem o organismo social, o qual, sendo vivo, não deixa de carregar no seu interior, sob o instituído, sob o organizado, os germes a partir dos quais a sociedade produz sua invenção e reinvenção da educação de seus membros, para, em cada momento, garantir a eficácia desta prática fundamental, pois "como a sociedade só pode existir nas consciências individuais e através delas é preciso que ela penetre e se organize em nós" (FEVR, p. 264). E, se primeiro foi a aldeia, depois as escolas cristãs e as corporações de mestres e aprendizes, e mais tarde a escola nacional, ou os sistemas públicos de ensino, ela não parou aí na busca de formas de tornar-se "parte integrante de nosso ser", que ela, para sobreviver, "educa e o faz crescer" (FEVR, p. 264). Se nesta busca viu, desde o século XVI, a escola ser atribuída ao Estado, como o lugar da educação, e como tal a concretizou no século XIX, então no século XX, quando em muitos rincões modernizados do planeta esta idéia não se 
concretizou ainda para todos, os meios de comunicação, com o advento dos satélites, se consolidam como a idéia que busca a solução da questão educacional, que se internacionaliza e se mundializa com o mundo.

Desta forma, a educação do cidadão ganha espaço teórico e prático em organismos supranacionais que, dedicando-se há cinqüenta anos ao objetivo de educar as mentes para a paz e a compreensão internacionais, apresentam entre suas mais recentes conclusões um aspecto que é central em Durkheim: "a solidariedade como condição de vida social". É o que Celso Furtado apresenta como síntese do trabalho da Comissão Mundial de Cultura e Desenvolvimento, convocada em 1992 pelo secretário geral da ONU e pelo diretor geral da UNESCO: "nossa civilização somente sobreviverá se lograr aprofundar os vinculos de solidariedade entre os povos e culturas em um sistema de convivência internacional cada vez menos tutelado e mais participativo" (FURTADO, 1995, p. 3). E o autor qualifica tal missão como resposta ao desafio de "conceber uma nova utopia" (FURTADO, 1995, p. 3), o que, pode-se dizer, guarda semelhança com a utopia de Durkheim, cuja preocupação e zelo com o nacional não o impediu de ver e pensar um mundo internacional. Em As Formas Elementares da Vida Religiosa (p. 351-9 e 502-4) o mundo internacional se evidencia como um fato histórico primitivo na existência dos deuses intertribais, e desde $A$ Divisão do Trabalho Social (v. 2, p. 163-4 e 203-4) se apresentava como ideal que se sobrepõe às nações em consolidação.

Já destacamos que Durkheim se coloca na posição de quem está pensando para o mundo. Em L'Éducation Morale ele é explícito ao expor a razão pela qual se pode afirmar que "nós pensamos para a bumanidade" ( $\mathrm{p}$. 237). Ressalta, neste sentido, o cosmopolitismo inerente ao povo francês, exemplificado no conteúdo universal de sua Constituição e das declarações dos direitos do homem (EPF, p. 314), do que conclui que a "função própria da educação é cultivar o bomem, desenvolver os germes de bumanidade que estão em nós" (EPF, p. 386). 
Apreendendo a continuidade do movimento sempre à frente do capitalismo enquanto processo civilizatório, Durkheim apreende, ao mesmo tempo, as questões sociais que se produzem neste e por este movimento, de que a miséria, o alcoolismo, o mal-estar coletivo são expressão concreta (EM, p. 71). Traz também para o âmbito de sua reflexão teórica a representação ideal destas questões sociais: o socialismo, visto como "um grito de dor, por vezes de cólera, lançado pelos bomens que mais vivamente sentem nosso mal-estar coletivo" (SO, p. 37). Desta perspectiva, o socialismo é considerado não como ciência, mas como ideologia e como fato social que deve ser estudado, pois representa uma força coletiva, necessidades sociais que devem ser compreendidas. Subjacente aos primeiros trabalhos de Durkheim, o estudo do socialismo não chega, entretanto, ao seu termo, fato do qual, segundo Marcel Mauss, Durkheim sempre se lamentou (SO, "Introdução", p. 30).

Estas duas questões - educação das novas gerações e socialismo -, desde sempre presentes em Durkheim, se unificam no seu pensamento, que se direciona para uma concepção global de educação no âmbito da nação, assim como para uma explicitação do papel do Estado moderno tal como este se representa na consciência moral moderna, o que implica a idéia de uma pátria moral, disciplinada, ou seja, que contenha o egoísmo expansionista e desenvolva em seu interior a aproximação máxima do ideal de humanidade.

Desta forma, a tendência ao universalismo indica, não só para a França, mas para todas as nações modernas, o caminho de um "patriotismo compreensivo", o respeito e o culto do indivíduo "in abstracto", daquilo que nele representa a humanidade. Durkheim afirma assim o nacional e o universal: uma pátria menor, já existente, e uma pátria maior, ainda ideal, da qual cada nação seria uma província - universalidade e pluralidade, em que "numa coletividade solidamente organizada" cada nação guardasse sua personalidade individual. Neste sentido, manifesta-se contra $\circ$ termo "internacionalismo", que implicaria nivelamento e não-consideração das 
pátrias existentes (CSA, p. 267). A idéia de pátria se coloca como necessária ao adulto, para nela "formar de maneira sã o espirito da criança" (CS $A$, p. 270), e se constitui também em objetivo a ser buscado na escola, onde se formam as mentes das novas gerações.

Durkheim busca o fundamento deste objetivo na gênese do "espirito do povo francês", para, compreendendo-o, reforçar os seus traços característicos, dentre os quais destaca o cosmopolitismo, a tendência à universalidade, atribuída ao racionalismo cartesiano, que conduz a uma configuração das coisas, não pelo individual e concreto que elas possuem, mas por suas formas gerais e abstratas, pelas quais o espírito humano pode se comunicar e comungar, pois são voltadas para o universal. Para ele, é necessário, conservando a tendência universalista, superar o simplismo geométrico inerente ao racionalismo francês e procurar noções gerais e inteligíveis, desenvolver o pensamento científico, isto é, o pensamento por conceitos determinados e definidos, conceitos distintos que apreendam o real em sua complexidade.

Assim, esta tendência universalista deve ser o centro do ensino do espírito coletivo a ser atingido através dos fatos históricos em cuja trama e desenvolvimento este espírito se revela, pois "o que é a bistória de um povo senão o gênio desse povo se desenvolvendo na história?” (EM, p. 236). A insistência no espírito coletivo do povo francês se justifica porque "é este o ponto no qual a consciência coletiva da França se encontra com a consciência bumana e com ela se confunde e, portanto, é por ele que também se confundem o patriotismo e o cosmopolitismo" (EM, p. 238).

Durkheim, ao conferir papel destacado à educação, esta se fazendo moral, e ao reconhecer nesta última sua origem religiosa, postula a sociologia como fundamento principal da pedagogia e da prática educativa por esta informada. Teoriza a racionalização e laicização da moral cioso de, neste processo, não empobrecê-la, mas, ao contrário, torná-la mais rica. Nesta busca, termina por divinizar a sociedade e o indivíduo, que se diferenciam, se personalizam, se socializam na dialética 
da coercitividade e desejabilidade em que ambos se superam: o indivíduo, em sua singularidade, na identificação com o coletivo, e a sociedade, internalizada pelas consciências individuais, no movimento em direção ao seu dever-ser, democrática e justa.

Querendo se libertar do dever-ser que parte de um a priori e projeta um futuro, Durkheim, como um filósofo, interroga a sua realidade partindo de uma visão de sociedade que ainda não é o que deve ser e cujas patologias então analisa. $\mathrm{Na}$ busca da constituição de uma ciência da moral, elabora uma teoria de investigação sociológica no interior de uma sociologia da cultura, em que a reflexão sobre as idéias, crenças, valores, práticas e instituições, dentre as quais a educação, tem como finalidade contribuir para busca da autoconsciência da sociedade. E a questão da sociologia, como ciência da educação, se articula com a questão da educação como cimento ideológico.

Fruto de um momento histórico em que a realidade se faz mais impenetrável, opaca, e escapa ao pensamento que quer apreendê-la, Durkheim recusa da sociologia, até então conhecida, a idéia do progresso como dogma de fé. Afirma a personalidade individual de cada sociedade, aberta ao possível, bem como a continuidade do seu desenvolvimento, cujo presente não se explica nele mesmo, mas na sua gênese, razão pela qual deve-se buscar no passado e nas condições nele dadas as instituições, práticas e valores, a fim de verificar a validade ou não das mesmas, em face das condições presentes, com vistas ao seu futuro, do qual Durkheim não escapa. E a ciência da moral se faz filosofia da educação, tornando compreensível o depoimento de Durkheim em carta a G. Davy, em que admite que, "tendo comecado da filosofia, propendo a voltar a ela: ou melhor, fui naturalmente trazido de volta a ela pela natureza das perguntas com que topei no caminho" (apud GIDDENS, 1978 , p. 46).

Têm sido assinaladas as ambigüidades do pensamento de Durkheim, as dificuldades teóricas com que se deparou no confronto com problemas insolúveis nos limites de seu sistema, que, expressando 
uma sociedade cindida, contraditória, se funda nas noções de solidariedade, de coesão social, de amor, de comunhão (FILLOUX, "Introdução", CSA). Apontam-se, por exemplo, problemas de estilo de sua linguagem figurativa e metafórica, que contribuem para uma compreensão distorcida de suas idéias e minimizadora da sua importância (LUKES, 1977, p. 34); a lógica dual que perpassa sua obra e empobrece a visão da realidade plural que ela busca explicar (ORTIZ, 1989b); os limites de soluções metodológicas e a extrapolação destes em generalizações discutíveis (LÉVI-STRAUSS, 1947, p. 205).

Estes aspectos revelam Durkheim como um pensador que denuncia a divisão e o estado de perturbação moral da realidade que ele afirma, negando seus sintomas patológicos, e na qual vislumbra valores emergentes que devem ser identificados pelo cientista, o moralista, o político, o pedagogo. Desta forma, sob a premissa de que "somente os tempos moralmente divididos são inventivos em matéria de moral" (IM, p. 316), explicita-se a esperança no futuro de uma sociedade em que a atividade produtiva se constituirá, não mais em um fim, um em-si na busca egoísta de sua autorealização, mas em meio de realização de uma sociedade em que se privilegie o desenvolvimento a serviço do que há de humano no indivíduo.

É neste sentido que é possível pensar numa utopia durkheimiana, na qual "ciência e ideologia se cotejam e se interpenetram" (ORTIZ, 1989b, p. 17), pois se alimentam de uma mesma realidade. Realidade esta que move, por inteiro, Durkheim: cientista, cidadão e educador. Admiração, obstinação, rigor, tenacidade, paixão.

A amplitude das preocupações de Durkheim, a complexidade e o antagonismo dos elementos que tensionam sua inquietação intelectual estão, sem nenhuma dúvida, no âmago das originalidades e ambigüidades apontadas pelos diversos estudiosos do seu pensamento. Mas o que sugere a leitura de Durkheim é, sobretudo, o fato de que as contradições inerentes à sociedade moderna, que não lhe passam desapercebidas, se 
esbatem nos limites de seu sistema de pensamento. Este não pode assimilar o princípio explicativo das mesmas, as quais ele situa, então, não na realidade mesma, que não pode produzir em suas próprias entranhas algo que lhe seja contrário, mas entre os ideais divergentes, entre si e em relação ao ideal coletivamente produzido, que aponta para a realização da sociedade em sua fase superior. É porque interpreta desta forma a contradição que Durkheim pode esperar a realização da harmonia pelo desenvolvimento da sociedade que se impõe aos indivíduos. É, ainda, porque estes, em sua interpretação, constituem um nós, cuja cisão ele não admite, que ele pode afirmar que, "vitimas de uma ilusão, pensamos ser de nossa elaboração aquilo que nos é imposto do exterior" (RMS, p. 4). O que não deixa de ser verdadeiro, embora não encerre toda a verdade. Mas, como o próprio Durkheim reconhece, o sonho de uma "ciência que exprima adequadamente o real (...) é um ideal de que nos podemos aproximar sem limite, mas que nos é impossivel atingir" (CS A, p. 294).

Pensador sensível ao social, inquieto e sabedor da complexidade e opacidade do mesmo, Durkheim parece ter ciência de suas ambigüidades, ao considerar que "o pensamento é, sem dúvida, uma fonte de alegrias e que podem ser muito vivas; mas simultaneamente quantas alegrias perturba! Para um problema resolvido, quantas questões levantadas que ficam sem respostas! Para uma dívida esclarecida, quantos mistérios apercebidos que nos desconcertam!" (DTS, v. 2, p. 19).

Abstract: This text looks for to associate the question of modernity to the sociological categories of Durkheim. In this context, it interests in first place its notion of pedagogy and of as if they associate, in its theory, educacion, moral and sociology.

Keywords: pedagogy, sociology, education 


\section{REFERÊNCIAS BIBLIOGRÁFICAS}

\subsection{Obras de Émile Durkheim (siglas utilizadas)}

A Ciência Social e a Ação. Trad. Inês Duarte Pereira. São Paulo, Difel, 1975 (CSA).

A Divisão do Trabalho Social. $2^{\mathrm{a}}$. ed., trad. Eduardo Freitas e Maria Inês Mansinho. Lisboa, Editorial Presença, s/d, vols. 1 e 2 (DTS).

As Formas Elementares da Vida Religiosa: o Sistema Totêmico na Austrália. Trad.

Joaquim Pereira Neto. São Paulo, Edições Paulinas, 1989 (FEVR).

As Regras do Método Sociológico. 14 $4^{\mathrm{a}}$.edição, trad. Maria Isaura Pereira de

Queiroz. São Paulo, Editora Nacional, 1990 (RMS).

"Definição e origem do socialismo". In FRIDMAN, Luis Carlos (org.).

Émile Durkbeim e Max Weber, Socialismo. Trad. Ângela Ramalho e

Antonia Bandeira. Rio de Janeiro, Relume-Dumará, 1993.

Éducation et Sociologie. $3^{\mathrm{a}}$ edição. Paris, Presses Universitaires de France, 1977 (ES).

"Introduction à la Morale". Textes, II. Paris, Minuit, 1975 (IM).

L'Éducation Morale. Paris, Presses Universitaires de France, 1974 (EM).

L'Évolution Pedagogique en France. $2^{\mathrm{a}}$ ed. Paris, Presses Universitaires de

France, 1969 (EPF).

Lif̧ões de Sociologia: a Moral, o Direito e o Estado. Trad. J. B. Damasco Penna. São Paulo, T. A. Queiroz/Edusp, 1983 (LS).

O Suicídio: estudo sociológico. $5^{\text {a }}$. edição, trad. Luz Cary, Margarida Garrido e

J. Vasconcelos Esteves. Lisboa, Editorial Presença, 1992 (OS).

Socialismo, trad. Ângela Ramalho. Rio de Janeiro: Relume-Dumará, 1993 (SO).

Sociologia e Filosofia. Trad. J. B. San Martin. São Paulo, Ícone, 1994 (SF). 


\subsection{Bibliografia (outros autores)}

ALPERT, Harry. Durkheim. 2 $2^{\mathrm{a}}$. ed., trad. José Medina Echavarría. México, Fondo de Cultura Económica, 1986.

AZEVEDO, Fernando de. Sociologia Educacional: introdusaão ao estudo dos fenômenos educacionais e de suas relą̧ões com outros fenômenos sociais. $5^{\mathrm{a}}$. ed. São Paulo, Edições Melhoramentos, s/d.

ARON, Raymond. As Etapas do Pensamento Sociológico. $2^{\mathrm{a}}$. ed., trad. Sérgio Bath. São Paulo, Livraria Martins Fontes Editora, 1987.

CHERKAOUI, Mohamed. "Système Social et Savoir Scolaire: les enjeux politiques de la distribuition des connaissances selon Durkheim". Revue Française de Science Politique, 28 (2), avril, 1978, p. 313-348.

FERNANDES, Florestan. Fundamentos Empiricos da Explicąão Sociológica. $2^{\text {a }}$. ed. São Paulo, Editora Nacional, 1972.

FERNANDES, Heloísa Rodrigues. Sintoma Social Dominante: um estudo sobre a Educaşão Moral em Émile Durkebim. São Paulo, Edusp/Escuta, 1994.

FILLOUX, Jean-Claude. "Introdução". In: DURKHEIM, Émile. $A$ Ciência Social e a Aģão. Trad. Inês Duarte Ferreira, São Paulo, Difel, 1975, p. 7-64.

FURTADO, Celso. "Cultura e Desenvolvimento". Folha de São Paulo, "Tendências e Debates", 05/11/1995, p. 1-3.

GIDDENS, Anthony. As Idéias de Durkheim. Trad. Octávio Mendes Cajado. São Paulo, Cultrix, 1978.

LACROIX, Bernard. Durkbeim y lo Politico. Trad. Aurelio Gazón del Camino. México, Fondo de Cultura Económica, 1984.

LATERZA, Moacir e RIOS, Teresinha A. Filosofia da Educaşão: fundamentos. São Paulo, Herder, 1971, vol. 2.

LÉVI-STRAUSS, Claude. "La Sociologie Française". In: GURVITCH, G. (org.). Sociologie au $X X^{r}$ 'Siècle: les études sociologiques dans les diférents pays. Paris, Presses Universitaires de France, 1947, vol. II, p. 513-545. 
LUKES Steven. Émile Durkheim, his Life and Work, a bistorical and critical study. England, Penguin Books, 1977.

ORTIZ, Renato. "Durkheim: um percurso sociológico 'Apresentação"'. In: DURKHEIM, Émile. As Formas Elementares da Vida Religiosa: o sistema totêmico na Austrália. São Paulo, Edições Paulinas, 1989a.

" "Durkheim: Arquiteto e Herói Fundador". Revista Brasileira de Ciências Sociais. ANPOCS, 11(4), out. 1989, p. 5-22. . "À Procura de uma Sociologia da Prática - 'Introdução"” In: ORTIZ, R. (org.). Pierre Bourdieu: Sociologia. São Paulo, Ática, 1983. 